\title{
Why can Mauritius export manufactures and Ghana not?
}

\author{
Francis Teal
}

WPS/99-10

March 1999

\begin{abstract}
Exports of labour-intensive manufactures from sub-Saharan Africa are negligible with the exception of Mauritius. Such exports from Ghana are low relative to other sub-Saharan African countries and relative to what would be predicted by its factor endowment. Firm level data from the two countries is used to assess the reasons for this poor performance. Large firms (those with more than 100 employees) are much more likely to be in the export market than smaller firms. It is shown that Mauritian firms are four times more efficient than those in Ghana while wages are six times higher. However for large firms the productivity differential is similar but wages in Mauritius are only three times those in Ghana. Large firms in Ghana cannot compete with those from Mauritius due to their high wages relative to productivity.
\end{abstract}

Key words: Productivity, wages, manufacturing exports, sub-Saharan Africa.

Acknowledgements: The data for the Ghanaian manufacturing sector used in this paper were collected by a team from the Centre for the Study of African Economies (CSAE), University of Oxford, the University of Ghana, Legon and the Ghana Statistical Office, Accra. The surveys were part of the Regional Program on Enterprise Development (RPED) organised by the World Bank. The questionnaire was designed by a team from the World Bank. The collection of the Zambian data, which is also part of the RPED research programme, was organised by a team from the Department of Economics at the University of Oslo. The Mauritian data was collected as part of a survey organised for the African Economic Research Consortium (AERC) by Dr Rajen Dabee of the University of Mauritius. I am greatly indebted to Professor Førsund and Dr Dabee for making their data available. The research was undertaken as part of the Trade and Enterprise Research Programme funded by the Department for International Development of the UK. The CSAE is funded by the Economic and Social Research Council of the UK.

Correspondence: Dr F J Teal, Centre for the Study of African Economies, Institute of Economics and Statistics, University of Oxford, St. Cross Building, Manor Road, Oxford, OX1 3UL, email: francis.teal@ economics.ox.ac.uk 


\section{Introduction}

The issue as to how sub-Saharan African countries can enter the market for manufactures is one of the most important policy issues facing governments in Africa. There are at least four views as to the reason for the low levels of manufactured exports from the continent. The first is that Africa's low levels of skills and relative abundance of natural resources ensure that exporting manufactures is unprofitable, Wood (1994), Wood and Berge (1997), Wood and Mayer (1998). It is possible that natural resource intensive economies will be able to efficiently export the goods in processed form, essentially if transport costs are sufficiently high to outweigh other cost disadvantages. Owens and Wood (1997) argue for sub-Saharan Africa that this is not the case. They find that processing requires higher levels of skills than are available in Africa. The second view is that African governments have created a high transaction costs environment in which export growth generally has been retarded. In this view, if present policies of openness can be sustained, then export growth, including that for manufactures, can be realised, Collier (1997), Collier and Gunning (1997). The third view sees the problem as the failure of policy to promote technological capabilities, by which is meant firm specific learning, which is seen as the basis for a successful process of industrialisation, Lal et al (1994). Finally, a view which has its origins in "new trade" theory, is that the key to successful exporting is the technical efficiency of firms. Such efficiency is determined by policies which encourage innovation, economies of scale, exposure to foreign competition and the availability of new goods, Krugman, (1984 and 1987) Grossman and Helpman (1991). These factors, not comparative advantage defined in terms of resource endowments, determine industrial success.

These explanations are not mutually exclusive. All seek to identify the source of costs to manufacturing firms in Africa that prevent their being internationally competitive. In seeking to test the hypotheses that underlie these views both macro and micro evidence has been used. In this paper we examine the manufacturing sector of two countries which have had very different outcomes for their manufacturing exports, Mauritius and Ghana. In the next sections we present macro and micro evidence for the growth of manufactures in sub-Saharan Africa to set these two countries in context. It is shown that Ghana is among the poorest performers in terms of manufacturing exports while Mauritius is, by far, the most successful economy in sub-Saharan Africa. In section 4 data for firm performance in Ghana and Mauritius is used to show which elements of the above explanations assist in understanding why Mauritius can export manufactures and Ghana cannot. A final section concludes.

\section{Exports of Manufactures from Africa: Macro Evidence}

The choice of countries presented in this section - the Cameroon, Ghana, Kenya, Mauritius, Zambia and Zimbabwe - is dictated by the availability of both micro and macro information on the performance of manufacturing exports. ${ }^{1}$ The micro evidence relates mostly to the period of the early 1990s. In this section we review the macro evidence on the growth of manufactured exports over the period since the mid 1970s. In the next section we review the micro data for the same countries. All the countries which we consider, with the exception of Mauritius, faced acute difficulties in their macroeconomic environment that had important implications for the performance of manufacturing exports.

The longer term comparative macroeconomic performance of the countries, over the period 1970 to 1995 , is shown in Table 1 . In the first part of the period, 1971-85, the highest rate

\footnotetext{
${ }^{1}$ There is firm level information for some other countries, Tanzania and Ethiopia are two examples, but this data is not yet in a form which enables comparisons to be made across countries.
} 
of growth was achieved by the Cameroon. Three of the countries experienced negative growth rates of income, Ghana, Zambia and Zimbabwe. Of these three only Ghana was able to reverse the poor performance; for Zambia and Zimbabwe there was no improvement while for the Cameroon the substantial falls in income resulted in a halving of per capita GDP in the decade. Kenya and Mauritius stand out as the two countries with relatively stable growth rates of per capita income. The difference between the two is in the rates. Mauritius grew by between 3-4 per cent per annum while, on average, the growth rate of growth in Kenya was less than 1 per cent. With the exception of the Cameroon all the countries saw an improvement in the growth rates of exports in the second part of the period. Again Ghana is the country which saw the most dramatic turnround with a trend fall in export volumes of 10.7 per cent being changed to a rise of 4.4 per cent. In Zambia the rapid fall in export volumes was halted but there is no evidence of sustained recovery at the level of aggregate exports. In contrast, for manufacturing exports, Zambia stands out as a relatively successful country over the period 1985-95; real manufacturing exports per capita grew very rapidly, far faster than any of the other countries surveyed. The growth rate for Ghana over this sub-period at 5.7 per cent was very similar to that for Mauritius of 6.7 per cent. While over the longer term, from 1970 to 1995 Mauritius stands out as the only one of the economies presented in the Table which successfully sustained growth of income and exports, such averages hide the magnitude of the turnround achieved by both Ghana and Zambia in their manufactured export growth.

\begin{tabular}{|c|c|c|c|c|c|c|}
\hline \multicolumn{7}{|c|}{$\begin{array}{l}\text { Table } 1 \\
\text { per Capita and Real Manufacturing Exports per Capita: } 1970-1985 \text { and } 1985-1995\end{array}$} \\
\hline & \multicolumn{2}{|c|}{ Real GDP per Capita } & \multicolumn{2}{|c|}{ Real Exports per Capita } & \multicolumn{2}{|c|}{$\begin{array}{l}\text { Real Manufacturing Exports } \\
\text { per Capita }\end{array}$} \\
\hline & $1971-85$ & $1985-95$ & $1971-85$ & $1985-95$ & $1975-85$ & 1985-95 \\
\hline Cameroon & 4.4 & -6.4 & 8.3 & -1.2 & 1.0 & -1.7 \\
\hline Ghana & -2.8 & 1.3 & -10.7 & 4.4 & 1.4 & 5.7 \\
\hline Kenya & 1.0 & 0.0 & -3.1 & 3.1 & -8.7 & 4.0 \\
\hline Mauritius & 2.6 & 4.3 & 1.7 & 5.1 & 10.9 (a) & 6.7 \\
\hline Zambia & -2.7 & -2.1 & -5.1 & 0.8 & $-5.9(b)$ & 15.5 \\
\hline Zimbabwe & -0.5 & -0.4 & -1.6 & -0.3 & $-6.3(c)$ & $0.3(\mathrm{c})$ \\
\hline \multicolumn{7}{|c|}{$\begin{array}{l}\text { (a) 1974-1985, (b) 1978-1985, (c) } 1977-1985 \text { and 1985-1994. } \\
\text { Source: World Bank Data. } \\
\text { Real GDP and Real exports are World Bank constant price series. Real manufacturing exports were obtained } \\
\text { by deflating the value of country export in US } \$ \text { by the US export unit value price series from the IMF } \\
\text { Financial Statistics. } \\
\text { The figures reported in the Table are the coefficients of a regression of the log of the series on time. }\end{array}$} \\
\hline
\end{tabular}

The growth rates shown in Table 1, for Ghana and Zambia, are from very low levels of manufacturing exports. Table 2 shows the percentage of exports which are manufactures, the amount of manufactured exports in US\$ and, to place the figures in context given the very 
different population sizes of the countries, the per capita figures. ${ }^{2}$ For only Zimbabwe and Mauritius are manufacturing exports a significant proportion of exports, 33 per cent in the case for Zimbabwe and 53 per cent for Mauritius (on average over the period 1980-95). In terms of exports per capita Mauritius is by far the most successful economy with export values over the period 1980 to 1995 rising from US\$ 341 to US\$ 823. A comparison of Tables 1 and 2 shows the nature of the rapid growth in manufactured exports which has occurred in Ghana and Zambia. Comparing the decade of the 1980s with the period 1990-95 both these countries witnessed a very substantial rise in per capita manufactured exports but from such a low level that in Zambia, where the rise was a near doubling, per capita exports at US\$ 16 were negligible compared to the Mauritius figure, over that period, of US\$823.

\begin{tabular}{|l|l|l|l|l|l|l|}
\hline Table 2 Manufactured Exports: 1980-1995 \\
\hline $\begin{array}{l}\text { Country } \\
\text { (Means) }\end{array}$ & \multicolumn{2}{l|}{$\begin{array}{l}\text { Percentage of Exports } \\
\text { which are Manufactures }\end{array}$} & \multicolumn{2}{l|}{$\begin{array}{l}\text { Manufactured Exports } \\
\text { (Millions of US \$) }\end{array}$} & \multicolumn{2}{l|}{$\begin{array}{l}\text { Manufactured Exports } \\
\text { per Capita } \\
\text { (US\$) }\end{array}$} \\
\hline & $1980-90$ & $1990-95$ & $1980-90$ & $1990-95$ & $1980-90$ & $1990-95$ \\
\hline Cameroon & 9 & 13 & 169 & 224 & 15 & 18 \\
\hline Ghana & 9 & 13 & 83 & 147 & 6 & 9 \\
\hline Kenya & 14 & 17 & 174 & 232 & 8 & 9 \\
\hline Mauritius & 48 & 67 & 352 & 899 & 341 & 823 \\
\hline Zambia & 6 & 16 & 70 & 132 & 9 & 16 \\
\hline Zimbabwe (a) & 33 & 34 & 492 & 573 & 56 & 56 \\
\hline $\begin{array}{l}\text { Source: World Bank Data. } \\
\text { (a) Zimbabwe is 1980 to 1994. }\end{array}$ & & & & & \\
\hline
\end{tabular}

Table 3 presents the rates of inflation, the rates of depreciation of the real exchange rate and real interest rates from 1980 to 1995 for the countries. All the countries, with the exception of the Cameroon and Mauritius, have in common highly variable rates of inflation. The variation in the change in real exchange rate across time for the countries is even greater. In Ghana real interest rates, measured simply as the difference between nominal rates and the rate of inflation, have moved from substantial negative to substantial positive numbers. All the countries reviewed, with the exception of the Cameroon, saw substantial declines in their real exchange rates from 1980 to 1989. In the case of Ghana and Zimbabwe this continued into the 1990s. It is possible these declines were important in enabling the expansion of manufactured exports to occur that was documented in Table 1.

${ }^{2}$ The shares shown in Table 2 are derived from World Bank data. These include some elements of processing in manufacturing exports. The shares therefore differ from those given in the work of Wood and Mayer (1998) which will be presented later. 


\begin{tabular}{|c|c|c|c|c|c|c|}
\hline & \multicolumn{2}{|c|}{$\begin{array}{l}\text { Rate of Inflation } \\
(\% \text { pa) }\end{array}$} & \multicolumn{2}{|c|}{$\begin{array}{l}\text { Change in Real Exchange } \\
\text { Rate (\% pa) }\end{array}$} & \multicolumn{2}{|c|}{$\begin{array}{l}\text { Real Rate of Interest } \\
(\% \text { pa) }\end{array}$} \\
\hline & 1980-89 & $1990-95$ & 1980-89 & 1990-95 & $1980-89$ & 1990-95 \\
\hline Cameroon & 8.8 & 6.8 & 1.1 & -2.2 & 0 & 3.4 \\
\hline Ghana & 36.7 & 24.8 & -3.5 & -1.6 & -17.6 & 7.8 \\
\hline Kenya & 11 & 20.4 & -2.7 & 3.6 & 2.3 & 4.9 \\
\hline Mauritius & 10.1 & 7.8 & -2.3 & 4.1 & 2.9 & 3.3 \\
\hline Zambia & 30.8 & 71.7 & -1.4 & 1.4 & -10.5 & -47.6 \\
\hline Zimbabwe & 11.9 & 22.9 & -3.0 & -2.1 & -3.4 & 1.6 \\
\hline \multicolumn{7}{|c|}{$\begin{array}{l}\text { Definitions and Sources: } \\
\text { Rates of inflation are derived from the CPI data given in the IMF Financial Statistics. The real interest rate } \\
\text { the nominal interest rates (the deposit rate in IMF statistics) less the rate of inflation. The real exchange rate } \\
\text { is defined as: } \\
\text { Domestic CPI/( US export price index multiplied by the nominal exchange rate). } \\
\text { The nominal exchange rate used is domestic currency to the US } \$ \text {. This is a crude measure of the real } \\
\text { exchange rate but it captures the most important aspects of the differences between nominal and real } \\
\text { exchange rate movements. }\end{array}$} \\
\hline
\end{tabular}

In Table 4 the results of an analysis of the determinants of manufactured exports from sub-Saharan Africa by Wood and Mayer (1998, Table 8) is presented for the countries on which this paper is focusing. The first column is the predicted share of manufactures in total exports. The second column shows the difference between the actual share and that predicted. (The sum of columns [1] and [2] is thus the actual share.) In the second part of Table 4 a similar presentation for the share of processed products in primary exports is given. It will be noted that for all the countries, except Zimbabwe, the predicted share for manufactures is below the actual, in the case of both Ghana and Zambia very substantially so. For processed products the actual share is above the predicted for all the countries except Mauritius. For Ghana the actual share of manufactured exports (ie excluding processing) was 3 per cent compared with a prediction of 30 per cent, while its actual level of processed products at 28 per cent was 9 per cent higher than the predicted one. The variables used to generate these predictions are the proportions of skilled labour to natural resources in the economies. It is clear that Ghana's manufacturing performance is poor relative to what would be predicted on the basis of its factor endowment while it exports more processed primary products than it "should" on the basis of an analysis its comparative advantage assessed in terms of skilled labour and natural resources. Among the countries reviewed Ghana and Zambia perform poorly relative to the others. .

The analysis of this section has shown that rapid export growth of manufactures from Africa has proved possible in the 1990s. However the level remains very low, both absolutely and relatively to what would be predicted by an analysis of comparative advantage. It appears there remains a lot of explaining to do. In the next section we consider the micro evidence 


\begin{tabular}{|c|c|c|c|c|}
\hline \multirow[b]{2}{*}{ Country } & \multicolumn{2}{|c|}{ Shares of manufactures in total exports } & \multicolumn{2}{|c|}{$\begin{array}{l}\text { Share of processed products in primary } \\
\text { exports }\end{array}$} \\
\hline & Predicted & $\begin{array}{l}\text { Actual minus } \\
\text { Predicted }\end{array}$ & Predicted & $\begin{array}{l}\text { Actual minus } \\
\text { Predicted }\end{array}$ \\
\hline Cameroon & 18 & -10 & 14 & 1 \\
\hline Ghana & 33 & -30 & 19 & 9 \\
\hline Kenya & 26 & -5 & 19 & 1 \\
\hline Mauritius & 80 & -18 & 38 & -30 \\
\hline Zambia & 16 & -12 & 21 & 76 \\
\hline Zimbabwe & 20 & 14 & 16 & 4 \\
\hline
\end{tabular}

\section{Exports of Manufactures from Africa: Micro Evidence}

In this section the micro evidence is reviewed. In Tables 5 and 6 evidence presented in Bigsten et al (forthcoming) is extended to include information on Mauritius and Zambia. The data for Mauritius is drawn from a small survey conducted in $1994 .{ }^{3}$ For the other countries the surveys were conducted over the period 1991 to 1995 . The data presented in this paper is taken from the first rounds of those surveys.

In Table 5 the export orientation by sector is presented while in Table 6 that by firm size. Export orientation is defined as the percentage of output of the firms that is exported. In Table 5 four sectors are used: food, textile and garments, wood and furniture and metal working, which includes machine manufacture. The table shows the percentage of firms that are exporting and the percentage of their output that is exported. The percentage of firms which were exporters varies greatly between the countries. At one end of the spectrum are Mauritius and Zimbabwe where over half of the firms export. At the other end of the spectrum are Ghana and Zambia with 8 per cent. Within the sectors there are also substantial differences across the countries. In the textile and garment sector the extremes are represented by Mauritius where 67 per cent firms export and Ghana where only 3 per cent do so. The other major difference between Mauritius and the other sub-Saharan firms is in the percentage of output that is exported. In Zimbabwe, which is closest to the pattern of Mauritius it is 11 per cent about one-quarter the level of Mauritius. The picture captured by the micro surveys is very similar to that observed in the macro data. Mauritius is an outlier within the group in terms of the extent of its manufactured exports. Among the other countries there is diversity around the much lower average level of exports with Zimbabwe and the Cameroon being relatively successful exporters while Ghana, Kenya and Zambia manage very modest levels of exports.

${ }^{3}$ While the sample size is small the findings which will be presented below of the relative success of Mauritian firms is entirely consistent with the much larger data set used by Milner and Wright (1998) to analyse the pattern of growth of the economy. 


\begin{tabular}{|c|c|c|c|c|c|}
\hline & Food & $\begin{array}{l}\text { Textile and } \\
\text { Garments }\end{array}$ & $\begin{array}{l}\text { Wood and } \\
\text { Furniture }\end{array}$ & $\begin{array}{l}\text { Metal } \\
\text { Working and } \\
\text { Machines }\end{array}$ & $\begin{array}{l}\text { All } \\
\text { Sectors }\end{array}$ \\
\hline $\begin{array}{l}\text { Cameroon } \mathrm{N} \\
\text { Percentage Exporting } \\
\text { Percentage Exported } \\
\text { Percentage Exported } \\
\text { if Exporting }\end{array}$ & $\begin{array}{l}32 \\
25 \\
5 \\
0\end{array}$ & $\begin{array}{l}19 \\
26 \\
31 \\
0\end{array}$ & $\begin{array}{l}23 \\
39 \\
25 \\
65\end{array}$ & $\begin{array}{l}42 \\
38 \\
10 \\
27\end{array}$ & $\begin{array}{l}116 \\
33 \\
11 \\
32\end{array}$ \\
\hline $\begin{array}{l}\text { Ghana } \quad \mathbf{N} \\
\text { Percentage Exporting } \\
\text { Percentage Exported } \\
\text { Percentage Exported } \\
\text { if Exporting }\end{array}$ & $\begin{array}{l}37 \\
0 \\
0 \\
\text { na }\end{array}$ & $\begin{array}{l}35 \\
3 \\
0.03 \\
25\end{array}$ & $\begin{array}{l}34 \\
18 \\
84 \\
6\end{array}$ & $\begin{array}{l}36 \\
11 \\
1 \\
8\end{array}$ & $\begin{array}{l}142 \\
8 \\
22 \\
8\end{array}$ \\
\hline $\begin{array}{l}\text { Kenya } \mathrm{N} \\
\text { Percentage Exporting } \\
\text { Percentage Exported } \\
\text { Percentage Exported } \\
\text { if Firm Exports }\end{array}$ & $\begin{array}{l}32 \\
22 \\
13 \\
60\end{array}$ & $\begin{array}{l}45 \\
16 \\
4 \\
25\end{array}$ & $\begin{array}{l}44 \\
18 \\
4 \\
24\end{array}$ & $\begin{array}{l}47 \\
34 \\
7 \\
21\end{array}$ & $\begin{array}{l}168 \\
23 \\
7 \\
30\end{array}$ \\
\hline $\begin{array}{l}\text { Mauritius } \quad \mathbf{N} \\
\text { Percentage Exporting } \\
\text { Percentage Exported } \\
\text { Percentage Exported } \\
\text { if Exporting }\end{array}$ & $\begin{array}{l}2 \\
50 \\
1 \\
2\end{array}$ & $\begin{array}{l}12 \\
67 \\
65 \\
98\end{array}$ & $\begin{array}{l}3 \\
67 \\
35 \\
53\end{array}$ & $\begin{array}{l}18 \\
50 \\
26 \\
52\end{array}$ & $\begin{array}{l}35 \\
57 \\
39 \\
68\end{array}$ \\
\hline $\begin{array}{l}\text { Zambia } \mathrm{N} \\
\text { Percentage Exporting } \\
\text { Percentage Exported } \\
\text { Percentage Exported } \\
\text { if Firm Exports }\end{array}$ & $\begin{array}{l}44 \\
5 \\
1 \\
15\end{array}$ & $\begin{array}{l}45 \\
13 \\
3 \\
21\end{array}$ & $\begin{array}{l}30 \\
7 \\
3 \\
48\end{array}$ & $\begin{array}{l}34 \\
6 \\
0.04 \\
1\end{array}$ & $\begin{array}{l}153 \\
8 \\
2 \\
21\end{array}$ \\
\hline $\begin{array}{l}\text { Zimbabwe } \mathrm{N} \\
\text { Percentage Exporting } \\
\text { Percentage Exported } \\
\text { Percentage Exported } \\
\text { if Firm Exports }\end{array}$ & $\begin{array}{l}36 \\
47 \\
5 \\
10\end{array}$ & $\begin{array}{l}72 \\
58 \\
15 \\
27\end{array}$ & $\begin{array}{l}21 \\
38 \\
8 \\
20\end{array}$ & $\begin{array}{l}29 \\
62 \\
9 \\
14\end{array}$ & $\begin{array}{l}158 \\
54 \\
11 \\
20\end{array}$ \\
\hline \multicolumn{6}{|c|}{$\begin{array}{l}\text { Source: The data for the Cameroon, Ghana, Kenya and Zimbabwe is based on that presented in Bigsten el al } \\
\text { (forthcoming) where some of their sectors have been aggregated to facilitate a comparison with data from } \\
\text { Zambia and Mauritius. The Zambian data is part of the Regional Program on Enterprise Development } \\
\text { (RPED) see von der Fehr et al (1994). The Mauritian data was collected as part of a survey organised for the } \\
\text { African Economic Research Consortium (AERC) by Dr Rajen Dabee of the University of Mauritius. For all } \\
\text { the countries except Mauritius, for which there is only one cross-section, the data presented is from the first } \\
\text { rounds of the surveys. N is the number of observations. }\end{array}$} \\
\hline
\end{tabular}




\begin{tabular}{|c|c|c|c|c|}
\hline & $\begin{array}{l}\text { Large } \\
>=100 \text { employees }\end{array}$ & $\begin{array}{l}\text { Medium } \\
>=30 \text { and }<100 \\
\text { employees }\end{array}$ & $\begin{array}{l}\text { Small } \\
<30 \text { employees }\end{array}$ & All \\
\hline $\begin{array}{l}\text { Cameroon N } \\
\text { Percentage Exporting } \\
\text { Percentage Exported } \\
\text { Percentage Exported } \\
\text { if Exporting }\end{array}$ & $\begin{array}{l}24 \\
79 \\
30 \\
38\end{array}$ & $\begin{array}{l}36 \\
31 \\
5 \\
15\end{array}$ & $\begin{array}{l}56 \\
14 \\
6 \\
41\end{array}$ & $\begin{array}{l}116 \\
33 \\
11 \\
32\end{array}$ \\
\hline $\begin{array}{l}\text { Ghana N } \\
\text { Percentage Exporting } \\
\text { Percentage Exported } \\
\text { Percentage Exported } \\
\text { if Exporting }\end{array}$ & $\begin{array}{l}15 \\
40 \\
12 \\
31\end{array}$ & $\begin{array}{l}21 \\
10 \\
5 \\
50\end{array}$ & $\begin{array}{l}106 \\
3 \\
1 \\
7\end{array}$ & $\begin{array}{l}142 \\
8 \\
2 \\
28\end{array}$ \\
\hline $\begin{array}{l}\text { Kenya N } \\
\text { Percentage Exporting } \\
\text { Percentage Exported } \\
\text { Percentage Exported } \\
\text { if Exporting }\end{array}$ & $\begin{array}{l}36 \\
61 \\
20 \\
33\end{array}$ & $\begin{array}{l}48 \\
29 \\
7 \\
24\end{array}$ & $\begin{array}{l}84 \\
2 \\
1 \\
26\end{array}$ & $\begin{array}{l}168 \\
23 \\
7 \\
30\end{array}$ \\
\hline $\begin{array}{l}\text { Mauritius N } \\
\text { Percentage Exporting } \\
\text { Percentage exported } \\
\text { Percentage Exported } \\
\text { if Exporting }\end{array}$ & $\begin{array}{l}12 \\
92 \\
62 \\
67\end{array}$ & $\begin{array}{l}10 \\
30 \\
11 \\
37\end{array}$ & $\begin{array}{l}13 \\
46 \\
39 \\
84\end{array}$ & $\begin{array}{l}35 \\
57 \\
39 \\
68\end{array}$ \\
\hline $\begin{array}{l}\text { Zambia N } \\
\text { Percentage Exporting } \\
\text { Percentage Exported } \\
\text { Percentage Exported } \\
\text { if Exporting }\end{array}$ & $\begin{array}{l}28 \\
25 \\
7 \\
29\end{array}$ & $\begin{array}{l}43 \\
7 \\
1 \\
7\end{array}$ & $\begin{array}{l}82 \\
2 \\
1 \\
13\end{array}$ & $\begin{array}{l}53 \\
8 \\
2 \\
21\end{array}$ \\
\hline $\begin{array}{l}\text { Zimbabwe N } \\
\text { Percentage Exporting } \\
\text { Percentage Exported } \\
\text { Percentage Exported } \\
\text { if Exporting }\end{array}$ & $\begin{array}{l}84 \\
77 \\
18 \\
23\end{array}$ & $\begin{array}{l}33 \\
58 \\
5 \\
9\end{array}$ & $\begin{array}{l}41 \\
2 \\
0.01 \\
1\end{array}$ & $\begin{array}{l}158 \\
54 \\
11 \\
20\end{array}$ \\
\hline
\end{tabular}


Table 7 Firm characteristics: by Sector

Employee is number of Employees, Monthly Wages is in US\$, Value-added and Capital are measured in purchasing power parity US\$, Education is in Years

\begin{tabular}{|c|c|c|c|c|c|}
\hline & Food & $\begin{array}{l}\text { Textile and } \\
\text { Garments }\end{array}$ & $\begin{array}{l}\text { Wood and } \\
\text { Furniture }\end{array}$ & $\begin{array}{l}\text { Metal } \\
\text { Working and } \\
\text { Machines }\end{array}$ & $\begin{array}{l}\text { All } \\
\text { Sectors }\end{array}$ \\
\hline $\begin{array}{l}\text { Ghana N } \\
\text { Employment } \\
\text { Monthly Wages } \\
\text { Value-added/ } \\
\text { Employee } \\
\text { Capital/ } \\
\text { Employee } \\
\text { Education }\end{array}$ & $\begin{array}{l}35 \\
50 \\
76 \\
6,761 \\
8,291 \\
\\
9.0\end{array}$ & $\begin{array}{l}36 \\
19 \\
36 \\
1,884 \\
\\
3,829 \\
9.2\end{array}$ & $\begin{array}{l}35 \\
79 \\
56 \\
3,935 \\
\\
7,829 \\
\\
9.5\end{array}$ & $\begin{array}{l}37 \\
55 \\
54 \\
7,410 \\
9,605 \\
9.6\end{array}$ & $\begin{array}{l}143 \\
51 \\
56 \\
5,009 \\
7,393 \\
\\
9.4\end{array}$ \\
\hline $\begin{array}{l}\text { Mauritius N } \\
\text { Employment } \\
\text { Monthly Wages } \\
\text { Value-added/ } \\
\text { Employee } \\
\text { Capital/ } \\
\text { Employee } \\
\text { Education }\end{array}$ & $\begin{array}{l}2 \\
136 \\
257 \\
41,405 \\
\\
55,984 \\
\\
10.3\end{array}$ & $\begin{array}{l}13 \\
169 \\
384 \\
13,396 \\
\\
3,284 \\
\\
10.2\end{array}$ & $\begin{array}{l}3 \\
200 \\
303 \\
94,955 \\
7,573 \\
\\
6.8\end{array}$ & $\begin{array}{l}18 \\
96 \\
322 \\
43,264 \\
\\
30,784 \\
\\
10.5\end{array}$ & $\begin{array}{l}36 \\
133 \\
339 \\
36,682 \\
\\
20,319 \\
\\
10.0\end{array}$ \\
\hline
\end{tabular}

From Table 6 it is clear that in all countries exporting firms are substantially larger in terms of employment than non-exporting firms. The importance of size has been noted by Berry (1993). This pattern is much less pronounced in Mauritius than in the other countries but the sample size is small. It is easy to understand why a certain minimum size is necessary for firms to be able to export. There are fixed costs of marketing and costs of access which require a certain scale of operations. On the basis of the evidence presented in Bigten et al (forthcoming) this minimum size appears to be firms with 100 employees. $^{4}$

The finding from the surveys is that while most African manufacturing firms do not export, most large firms do. The exceptions are Ghana and Zambia. The failure of large firms to export from Zambia may be due to the extent of state involvement in that country, until relatively recently, however it clearly cannot account for the failure of such firms in Ghana. The contrast between Ghana and Mauritius across both sector and size is striking. In Ghana exporting is confined to the wood sector where it consists of processing timber products. ${ }^{5}$ This sector is relatively capital intensive within Ghanaian manufacturing. In Mauritius exporting is concentrated in the garment sector which is, by far, the most labour intensive sector. While in

${ }^{4}$ Bigsten et al (forthcoming) show that for the Cameroon, Ghana, Kenya and Zimbabwe, 71 per cent of firms with more than 100 employees export while for those with from 29 to 100 employees the number is 35 per cent. For firms smaller than 30 only a negligible proportion enter the export market, their Table 3.

${ }^{5}$ The aggregation in Table 5 hides this fact which can be seen in Bigsten et al (forthcoming, Table 2). 
Mauritius 90 per cent of large firms export, only 40 per cent of large Ghanaian firms enter the export market. The picture at the micro level closely mirrors that from the macro data. What exporting occurs within Ghanaian manufacturing is in the form of processing, there are virtually no labour intensive manufactures. In the next section we examine whether more detailed information on the firms in the two countries can explain these facts.

Table 8 Firm characteristics: by Size

Employee is number of Employees, Monthly Wages is in US\$, Value-added and Capital are measured in purchasing power parity US\$, Education is in Years

\begin{tabular}{|c|c|c|c|}
\hline & $\begin{array}{l}\text { Large Firms } \\
(>=100 \text { employees })\end{array}$ & $\begin{array}{l}\text { Small Firms } \\
(<100 \text { employees) }\end{array}$ & All Firms \\
\hline Ghana N & 20 & 123 & 143 \\
\hline Employment & 231 & 21 & 51 \\
\hline Monthly Wages & 100 & 47 & 56 \\
\hline Value-added/ & & & \\
\hline Employee & 11,067 & 4,024 & 5,009 \\
\hline Capital/ & & & \\
\hline Employee & 22,778 & 4,891 & 7,393 \\
\hline Education & 11.1 & 9.1 & 9.4 \\
\hline Mauritius N & 12 & 24 & 36 \\
\hline Employment & 330 & 35 & 133 \\
\hline Monthly Wages & 279 & 369 & 339 \\
\hline Value-added/ & & & \\
\hline Employee & 37,898 & 36,075 & 36,682 \\
\hline Capital/ & & & \\
\hline Employee & 12,885 & 24,036 & 20,319 \\
\hline Education & 11.1 & 9.5 & 10.0 \\
\hline
\end{tabular}

\section{$4 \quad$ Firms in Ghana and Mauritius}

What do Mauritian firms have that Ghanaian firms do not? Plausible answers to that question include, a better macro-economic environment, a better trained work force and more efficient firms. We have already shown that the macro environment for Ghana has improved and that in terms of the growth rate for its manufactured exports they were similar to those for Mauritius in the early 1990s. What of firm efficiency and training?

If firms in Ghana are internationally uncompetitive it must be that their wages are too high for their levels of productivity. In Table 7 we present the data for productivity and wage differentials between the two countries. Monthly wages in Mauritius are US\$339 per month and in Ghana US\$56, a differential of six times. If capital costs are the same in the two countries then the issue is whether labour productivity differentials are more than six times higher in Mauritius. There are two ways of investigating the differences in underlying productivity between the two countries. One is to compare the two production functions, the second is to use a dummy variable in a pooled regression. Both methods will give similar results if the underlying form of the production function is the same in the two countries. In Table 9 individual and pooled regressions for the determinants of productivity in the two countries are presented.

The measure of productivity is value-added per employee where value-added has been converted to purchasing power parity US dollars so it can be compared across countries. We 
consider three factors determining value-added; labour, physical capital and human capital. Labour is simply the total number of employees in the firm. Physical capital is the replacement value of capital to the firm valued at purchasing power parity dollars. Human capital is measured as the average years of education of workers in the firm.

\begin{tabular}{|c|c|c|c|}
\hline \multicolumn{4}{|c|}{$\begin{array}{l}\text { Table } 9 \text { The Determinants of Productivity } \\
\text { Dependent Variable: Ln (Value-added/Employee in US ppp\$) }\end{array}$} \\
\hline & Mauritius & Ghana & Pooled \\
\hline Constant & $\begin{array}{l}8.29 \\
{[3.3]^{* *}}\end{array}$ & $\begin{array}{l}5.25 \\
{[7.1]^{* *}}\end{array}$ & $\begin{array}{l}6.86 \\
{[9.5]^{* *}}\end{array}$ \\
\hline $\begin{array}{l}\text { Ln (Capital/ } \\
\text { Employee) }\end{array}$ & $\begin{array}{l}0.28 \\
{[2.3]^{*}}\end{array}$ & $\begin{array}{l}0.35 \\
{[6.9]^{* *}}\end{array}$ & $\begin{array}{l}0.37 \\
{[8.4]}\end{array}$ \\
\hline Ln (Employment) & $\begin{array}{l}-0.01 \\
{[0.1]}\end{array}$ & $\begin{array}{l}0.18 \\
{[1.8]}\end{array}$ & $\begin{array}{l}0.12 \\
{[1.5]}\end{array}$ \\
\hline Ln (Education) & $\begin{array}{l}-0.34 \\
{[0.4]}\end{array}$ & $\begin{array}{l}-0.29 \\
{[0.8]}\end{array}$ & $\begin{array}{l}-0.27 \\
{[0.9]}\end{array}$ \\
\hline Food & $\begin{array}{l}0.22 \\
{[2.3]}\end{array}$ & $\begin{array}{l}0.44 \\
{[1.8]}\end{array}$ & $\begin{array}{l}0.39 \\
{[1.8]}\end{array}$ \\
\hline $\begin{array}{l}\text { Textile and } \\
\text { Garments }\end{array}$ & $\begin{array}{l}-0.67 \\
{[1.5]}\end{array}$ & $\begin{array}{l}-0.01 \\
{[0.02]}\end{array}$ & $\begin{array}{l}-0.43 \\
{[1.3]}\end{array}$ \\
\hline $\begin{array}{l}\text { Wood } \\
\text { and Furniture }\end{array}$ & $\begin{array}{l}0.48 \\
{[0.6]}\end{array}$ & $\begin{array}{l}-0.01 \\
{[0.04]}\end{array}$ & $\begin{array}{l}0.05 \\
{[0.2]}\end{array}$ \\
\hline Ghana Dummy & & & $\begin{array}{l}-1.57 \\
{[6.1]^{* *}} \\
\end{array}$ \\
\hline Adjusted $\mathrm{R}^{2}$ & 0.27 & 0.37 & 0.53 \\
\hline $\mathrm{N}$ & 36 & 139 & 175 \\
\hline White $\chi^{2}(\mathrm{df})$ & $18(18)$ & $27(20)$ & $23(28)$ \\
\hline
\end{tabular}

The equations presented in Table 9 show that the determinants of productivity are similar across the two countries. The coefficients on physical capital are similar and the human capital variable is not significant for either country. The underlying productivity differential between Ghana and Mauritius is 3.8 times [exp(1.57) - 1]. In round numbers Mauritian firms are four times more efficient than those in Ghana. However average wages are six times higher in Mauritius so firms in Ghana, even with these low levels of productivity, should be more profitable for their owners. There is no evidence for either country of increasing returns to scale, ie controlling for the capital labour ratio large firms do not have higher labour productivity than small ones. However, as noted in the previous section, the evidence from across sub-Saharan Africa suggests that firms can only export if they reach a minimum size of 100 employees. The data in Table 8 show that for these firms the wages in Mauritius are only three times those in Ghana. Thus the Ghanaian firms which are large enough to enter the export market firms have 
higher unit cost than those in Mauritius: productivity in Mauritius is four times higher and wages are only three times higher than in Ghana.

\section{Conclusions}

We have examined four possible explanations for the poor performance of manufactured exports from Ghana relative to Mauritius, all related to arguments why underlying costs will be higher in Ghana than in Mauritius. The argument that these higher costs results from the low ratios of skilled labour to natural resources led to a predicted manufacturing export share substantially higher than that observed ( 33 rather than 3 per cent). If such costs play a role they are a far from complete explanation for poor Ghanaian performance. Macroeconomic policy has improved and in the 1990s the growth rate of Ghanaian manufactured exports was similar to that of Mauritius. It needs, however, greatly to exceed that of Mauritius if the gap between the economies is to be closed. The final two explanations reviewed in the introduction focused on differences in technical efficiency across the firms. This has been shown to be very important - Mauritian firms are four times more efficient than those in Ghana. Their average wages are six times higher so, while differential efficiency is important, it cannot be the whole explanation. The data suggests there is a strong link within Ghana between wages and firm size. For firms able to enter the export market, which the data shows needs to be those with more than 100 employees, wages are only three times higher in Mauritius while productivity remains four times higher. These results provide important insights into the reasons for the poor export performance of Ghanian manufacturing firms relative to those in Mauritius. For those firms able to export wages are too high to enable the firms to compete given the efficiency at which the firms operate.

\section{References}

Berry A. 1993 "Firm or Plant Size in the Analysis of trade and Development." In G.Helleiner, ed., Trade policy, Industrialization and Development: New perspectives. Oxford: Clarendon Press. Bigsten, A., P. Collier, S. Dercon, M. Fafchamps, B.Gauthier, J.W. Gunning,

J. Habarurema, A. Isaksson, A. Oduro, R. Oostendorp, C. Pattillo, M. Soderbom, F.Teal, A. Zeufack (forthcoming) "Exports of African Manufactures: Macro Policy and Firm Behaviour", Journal of International Trade and Development.

Collier, P. (1997) Globalisation: What should be the African policy response, CSAE, Oxofrd, mimeo.

Collier, P. and J.W. Gunning (1997) Explaining African Economic Performance, CSAE Working Paper 1997.2, Oxford, forthcoming Journal of Economic Literature.

von der Fehr, N., F. Forsund, S. Kittelsen, K.O. Moene, A. Torgersen (1994) The Zambian RPED Enterprise Database, Department of Economics, University of Oslo, mimeo.

Grossman, G. and E. Helpman. (1991) Innovation and growth in the Global Economy, Cambridge, Mass: MIT Press.

Krugman P. (1984) "Import Protection as Export Promotion : Internal Competition in the presence of oligopolies and economies of scale" In Kierkowski H. ed, Monopolistic Competition and International trade, Oxford University Press.

Krugman, P. (1987) "The Narrow Moving Bank, the Dutch Disease and the competitive Consequences of Mrs Thatcher : Notes on trade in the presence of Dynamic Scale Economies." Journal of Development Economics 27: 41-55.

Lall, S., Navaretti, G., Teitel, A. and Wignaraja, G. (1994) Technology and Enterprise Development: Ghana under Structural Adjustment, Macmillan. 
Milner, C. And P. Wright (1998) "Modelling labour market adjustment to trade liberalisation in an industrialising economy", Economic Journal, Vol 108, N0.447, March:509-528.

Owens, T. and A. Wood (1997) 'Export Oriented Industrialisation through Primary Processing?', World Development, 25 (9), September, 1453-1470.

Wood, A. (1994) North-South Trade, Employment and Inequality: Changing fortunes in a skilldriven world, Clarendon Press, Oxford.

Wood, A. and K. Berge (1997) "Exporting Manufactures: Human Resources, Natural Resources, and Trade Policy", Journal of Development Studies, 34 (1), 35-59.

Wood, A. and J. Mayer (1998) Africa's Export Structure in a Comparative Perspective, Study No. 4, African Development in a Comparative perspective, UNCTAD, Geneva. 